\title{
A Suppressor T Cell of the Mixed Lymphocyte Reaction Specific for the $H L A-D$ Region in Man
}

\author{
Edgar G. Engleman and Hugh O. MCDevitt, Division of Immunology, Department \\ of Medicine, Stanford University School of Medicine, Stanford, California 94305
}

A B S T R A C T The mixed lymphocyte reaction (MLR) is the proliferative response of one individual's lymphocytes cultured in the presence of another individual's lymphocytes. In man, the MLR is elicited by cell surface antigens coded for by the HLA-D gene locus. This locus is among a cluster of genes which are located on the sixth chromosome and which include genes coding for the major histocompatibility antigens $H L A-A, B$, and $C$ as well as $H L A-D$. If the stimulator cell possesses $D$ locus antigens not present in the responder, the lymphocytes of the latter will undergo blast transformation resulting in DNA synthesis which can be measured. A vigorous response in the MLR to allogeneic cells is the rule among healthy individuals.

We describe studies of a 23-yr-old man whose lymphocytes respond normally to mitogens and soluble antigens but fail to respond to allogeneic cells in the MLR. His medical history is unremarkable except that he received thymic irradiation as an infant. HLA typing revealed that he is homozygous for HLA-A2, B12, and Cw5 as well as for the $D$ locus antigen Dw4. When his lymphocytes were added to the responder lymphocytes of other persons homozygous for the same HLA antigens, their responses to allogeneic cells but not mitogens were suppressed by $50-95 \%$. Their responses to a soluble antigen, tetanus toxoid, were suppressed to a lesser degree. These inhibitory effects were mediated by a relatively radioresistant thymus-derived $(\mathrm{T})$ lymphocyte.

Further studies of the requirements for MLR suppression revealed that only persons heterozygous or homozygous for the Dw4 antigen were inhibited by the suppressor $\mathrm{T}$ cell. This effect was not altered by differences in the HLA-A, B, or C antigens between the suppressor and responder. It is concluded that genes in or near the HLA-D locus code not only for antigens (primarily on bone marrow-derived (B) cells), that elicit

Dr. Engleman is supported by an American Cancer Society California Division Fellowship.

Received for publication on 22 August 1977 and in revised form 8 November 1977. the MLR, but also for structures on T cells, or possibly macrophages, which are recognized by MLR suppressor T cells.

\section{INTRODUCTION}

In all species studied, stimulation in the mixed lymphocyte reaction (MLR) ${ }^{1}$ is controlled primarily by genes in the major histocompatibility complex, a cluster of genes which has been demonstrated to influence several functions of the immune system (1-3). In man, this gene complex termed human leukocyte antigen (HLA) is located on the sixth chromosome and includes genes determining the structure of the serologically defined transplantation antigens, HLA-A, B, and C, as well as the HLA-D antigens which elicit the MLR (4).

Unlike the serologically defined antigens, $D$ locus antigens can, at present, be recognized only by the "one-way" MLR. In this test, lymphocytes from one individual (the responder) are cultured with $x$-irradiated or mitomycin C-treated lymphocytes of the second individual (the stimulator). If the stimulator possesses $D$ locus antigens not present in the responder, the lymphocytes of the latter will undergo blast transformation, resulting in DNA synthesis which can be measured by incorporation of $\left[{ }^{3} \mathrm{H}\right.$-]thymidine. $\mathrm{X}$-irradiation or mitomycin $\mathrm{C}$ treatment prevents stimulator cells from undergoing transformation. Cells from one individual will not respond in the MLR to cells from an individual sharing his MLR ( $D$ locus) type, either as an identical heterozygote, or if homozygous for one of the responder's two $D$ locus types. With this test, it is possible to type for $D$ locus specificities.

In our studies of $H L A-D$, two persons repeatedly failed to respond in the MLR to one or more $x$-irradiated allogeneic cells. One of these individuals, a multiparous woman, responded to most allogeneic cells but not to her husband's, and when her thymus-derived (T)

${ }^{1}$ Abbreviations used in this paper: Con A, Conconavalin A; FCS, fetal calf serum; M199, medium 199; PHA, phytohemagglutinin. 
cells were added to the responder lymphocytes of HLA identical persons, their responses to her husband's cells were suppressed (5). The responses of HLA nonidentical persons were not suppressed. Because identity at the $D$ locus was required between suppressor and responder to avoid allogeneic interaction, persons heterozygous for the suppressor's haplotype could not be evaluated reliably for suppressibility. Also, it was not possible to map the genes controlling suppression because in our panel of HLA-B, D homozygous donors identity at the $D$ locus was always accompanied by identity at the serologically defined $B$ locus between suppressor and suppressed cells.

We now report studies of a second individual whose lymphocytes failed to respond in the one-way MLR, and whose $T$ cells suppressed the responses of certain co-cultured lymphocytes to allogeneic cells. The event which may have triggered the MLR suppressor cell in this individual, a healthy 23-yr-old man, was thymic irradiation received at the age of $5 \mathrm{wk}$. Unlike the previously reported subject with suppressor cells, the present individual's lymphocytes are only weakly responsive to the majority of allogeneic-stimulating cells, enabling studies of interaction between the suppressor cell and responder cells heterozygous for the suppressible haplotype. Furthermore, because the suppressor cell is homozygous for HLA-Dw4, an antigen lacking strong linkage disequilibrium with particular serologically defined A or B antigens, it was possible to test several different combinations of $\mathrm{A}, \mathrm{B}$, and $D$ determinants and thereby to map the gene or genes coding for suppressibility to the $H L A-D$ locus, or to a locus closely linked to $H L A-D$.

\section{METHODS}

Blood samples were obtained from a panel of healthy persons known to be homozygous or heterozygous for specific HLA antigens. All experiments were performed with lymphocytes from fresh venous blood.

Mixed lymphocyte cultures. As described (5), mononuclear leukocytes from defibrinated blood were collected by Ficoll-Hypaque (Ficoll, Pharmacia Fine Chemicals, Div. Pharmacia Inc., Piscataway, N. J.-Hypaque, Winthrop Laboratories, Evanston, Ill.) gradient centrifugation, washed and then resuspended at $1 \times 10^{6} \mathrm{cells} / \mathrm{ml}$ in RPMI 1640 medium (Grand Island Biological Co., Grand Island, N. Y.) containing $100 \mathrm{U} / \mathrm{ml}$ penicillin, $100 \mu \mathrm{g} / \mathrm{ml}$ streptomycin, $2 \mathrm{mM}$ glutamine, and $10 \%$ pooled human type A serum. Stimulating cells were irradiated in a ${ }^{137} \mathrm{Cs}$ irradiator (Mark I model 24 irradiator, J. L. Shepherd, Glendale, Calif.) with a dose of 6,000 rads to abolish their capacity to proliferate and to make the reaction unidirectional. Mixed lymphocyte cultures were carried out in round-bottomed microtiter trays (Linbro Chemical Co., Hamden, Conn.) with 50,000 responder cells and 50,000 irradiated stimulators in a volume of $0.15 \mathrm{ml}$. In three-way cultures, 50,000 suppressor cells were co-cultured with 50,000 responder cells and 50,000 irradiated stimulator cells in $0.15 \mathrm{ml}$. Cultures, prepared in triplicate or sextuplicate, were incubated in air $/ 5 \% \mathrm{CO}_{2}$ for 6 days at $37^{\circ} \mathrm{C}$. $\left[{ }^{3} \mathrm{H}\right]$ thymidine (New England Nuclear, Boston, Mass.) was then added, 1 $\mu \mathrm{Ci} /$ well, and the plates harvested in a multiple sample harvester (MASH II Microbiological Associates, Walkersville, Md.) $18 \mathrm{~h}$ later.

Quantitation of $T$ cells, bone marrow-derived (B) cells, and monocytes. Mononuclear cells from Ficoll-Hypaque gradients were washed once at room temperature in phosphate-buffered saline before resuspension in culture medium 199 with $5 \%$ fetal calf serum (M 199-FCS) at $2 \times 10^{6} \mathrm{cells} / \mathrm{ml}$. The monocyte fraction was determined by staining with $\alpha$-naphthyl acetate according to the method of Yam et al. (6) The Ig-bearing lymphocyte fraction was determined by labeling with a fluorescein-conjugated goat anti-human Ig antiserum (Microbiological Research, Bountiful, Utah) as described (6). The percentage of fluorescent small lymphocytes was determined using a Zeiss microscope equipped with a tungsten light source and a fluorescein isothiocynate excitation filter. This method of staining Ig-bearing lymphocytes might stain, in addition to $\mathrm{B}$ lymphocytes, cells with either Fc receptors or cytophilic Ig. Monocytes were excluded by histologic criteria.

A specific anti-T cell serum was used in an in vitro cytotoxicity assay for measuring peripheral blood $T$ cells. This serum was prepared in the laboratory of Dr. Samuel Strober at Stanford University by extensively absorbing a goat anti-human thymocyte antiserum with human erythrocytes and buffy-coat cells from a patient with chronic lymphocytic leukemia (7). $10 \mu \mathrm{l}$ of a suspension of target cells $\left(2 \times 10^{6}\right.$ cells $\left./ \mathrm{ml}\right)$ were added to $10 \mu \mathrm{l}$ of anti-T cell antiserum or normal goat serum diluted 1:4 in M199-FCS. Cells were allowed to incubate for $15 \mathrm{~min}$ at room temperature after which $5 \mu \mathrm{l}$ of guinea pig complement diluted 1:4 were added. The mixture was incubated at room temperature for an additional $45 \mathrm{~min}$ before centrifugation at $250 \mathrm{~g}$ for $5 \mathrm{~min}$. The pellet was resuspended in $10 \mu \mathrm{l}$ of $\mathrm{M} 199$, and $5 \mu \mathrm{l}$ of a $0.4 \%$ trypan blue solution in M199 added before counting in a standard hemocytometer.

Separation of T cells and B cells. Peripheral blood T and B cells were separated by two methods. The first method is dependent on B lymphocytes binding to a plastic flask coated with anti-immunoglobulin (5) and the second uses rosetting of $T$ cells which have bound sheep erythrocytes (8). In the first method, $2 \mathrm{ml}$ of Cohn fraction II immunoglobulin $(2 \mathrm{mg} / \mathrm{ml}$; Mann Research Laboratories, Inc., New York) and watersoluble dicarbodiimide $(1 \mathrm{mg} / \mathrm{ml})$ in phosphate-buffered saline were incubated in a plastic tissue flask (Falcon Plastics, Div. of BioQuest, Oxnard, Caif.) for $1 \mathrm{~h}$ at room temperature. After the flask was washed with PBS-5\% FCS, $2 \mathrm{ml}$ of a 1:20 dilution of rabbit anti-human immunoglobulin was added and incubated for $30 \mathrm{~min}$ at room temperature. $1.5 \times 10^{7} \mathrm{Ficoll}-\mathrm{Hy}$ paque enriched mononuclear cells in RPMI 1640-10\% FCS were then added and allowed to stand for $30 \mathrm{~min}$ at room temperature. Under these conditions monocytes as well as $B$ cells adhere to the flask. The nonadherent $\mathrm{T}$ cells were decanted and the $\mathrm{B}$ cells removed after $2 \mathrm{~h}$ incubation at $37^{\circ} \mathrm{C}$ with RPMI-50\% Human A serum containing $1.25 \mathrm{mM}$ EDTA. T cells were measured in the two fractions by rosetting. Cell recovery was normally $75-90 \%$.

In the second method, fractions enriched for T or B cells were obtained by a sheep cell rosetting technique. $5 \times 10^{6}$ Ficoll enriched cells/ml in RPMI-10\% FCS were pelleted with $0.7 \%$ papain-treated sheep erythrocytes. After $1 \mathrm{~h}$ at $4^{\circ} \mathrm{C}$, the $T$ cell rosettes were separated from the B cells and monocytes by centrifugation over $10 \%$ Ficoll-Hypaque. The rosettes were dissociated by incubation at $37^{\circ} \mathrm{C}$ for $10-20 \mathrm{~min}$ with frequent vortex mixing and $\mathrm{T}$ cells separated from the sheep erythrocytes on another Ficoll-Hypaque gradient.

Cell mediated antibody-dependent lympholysis. The method described by Kovithavongs et al. (9) was used. $5 \times 10^{6}$ target lymphocytes in $0.1 \mathrm{ml}$ RPMI 1640-10\% FCS were 
labeled by incubating with $100 \mu \mathrm{Ci}{ }^{51} \mathrm{Cr}$ (New England Nuclear) for $1 \mathrm{~h}$ at $37^{\circ} \mathrm{C}$ with shaking. $2 \times 10^{6}$ effector cells in 1 $\mathrm{ml}$ RPMI 1640-10\% FCS were added to $0.01 \mathrm{ml}(100,000)$ labeled target cells in triplicate. $0.1 \mathrm{ml}$ of normal human serum "antibody" was then added and the mixture incubated for $4 \mathrm{~h}$ at $37^{\circ} \mathrm{C}$. The cells were centrifuged to a pellet, and the ${ }^{51} \mathrm{Cr}$ released into the supernate counted in a gamma counter. Variability between triplicate samples never exceeded $10 \%$ and averaged $5 \%$. The percentage of ${ }^{51} \mathrm{Cr}$ released for each combination was derived by dividing the observed release minus background release (target cell incubated alone) by the maximum available for release (by hypotonic rupture) minus background. Maximal ${ }^{51} \mathrm{Cr}$ release by hypotonic lysis of target cells varied from 75 to $85 \%$.

Stimulation with mitogens. Stimulation with Concanavalin A (Con A, Pharmacia Fine Chemicals), or phytohemagglutinin (PHA, The Wellcome Foundation, Ltd., The Wellcome Research Laboratories, Beckenham, Kent, England) was carried out in air $/ 5 \% \mathrm{CO}_{2}$ for 4 days at $37^{\circ} \mathrm{C}$. 100,000 peripheral blood mononuclear leukocytes were incubated in round-bottomed microtiter wells (Grand Island Biological) in 0.2 $\mathrm{ml}$ of RPM 1 1640-10\% pooled human A serum and either $1 \mu \mathrm{g}$ Con A or $1 \mu \mathrm{g}$ PHA. Assays were performed in triplicate. $\left[{ }^{3} \mathrm{H}\right]$ thymidine $1 \mu \mathrm{Ci} /$ well, was added $18 \mathrm{~h}$ before harvesting. Stimulation with soluble antigens. Stimulation with tetanus toxoid (alum adsorbed, Wyeth, final dilution 1:20,000) and diphtheria toxoid (alum adsorbed, Sclavo, final dilution $1: 2,000)$ was carried out in air $/ 5 \% \mathrm{CO}_{2}$ for 7 days at $37^{\circ} \mathrm{C}$. 100,000 or 200,000 Ficoll-Hypaque enriched peripheral blood mononuclear cells were incubated with these antigens in flat- bottomed microtiter wells (Cooke Laboratory Products Div. Dynatech Laboratories, Inc., Alexandria, Va.). Assays were performed in sextuplicate. $\left[{ }^{3} \mathrm{H}\right]$ thymidine $(1 \mu \mathrm{Ci} /$ well $)$ was added $18 \mathrm{~h}$ before harvesting. In two-cell cultures, 100,000 cells from each of two donors were co-cultured in the presence of the same concentrations of the above antigens.

\section{RESULTS}

Shortly after birth the propositus, M. M., was treated with thymic irradiation for "failure to thrive". At $5 \mathrm{wk}$ and again at 6 -wk old, he received 128 rads in $1.5 \mathrm{~min}$ to a $10 \times 10-\mathrm{cm}$ field in the anterior mediastinum (targetskin distance of $50 \mathrm{~cm}$ ). M. M.'s childhood development was entirely normal, and at the time of this report, he is a healthy 23-yr-old caucasian male. None of M. M.'s eight siblings or his parents received thymic irradiation, and their medical histories are unremarkable.

$M L R$ in the family $M$. The HLA types of the members of family $\mathbf{M}$ are shown in Table I. M. M., his HLA identical sibling, B. M., and their mother, L. M., are homozygous for HLA-B12. In the MLR, responses of $<10,000 \mathrm{cpm}$ or relative responses of $<30 \%$ are considered to be nonstimulatory in this laboratory. By these criteria, the latter three cells stimulate none of the other family members in the MLR, and have been

TABLE I

HLA and MLR Data on Family M

\begin{tabular}{|c|c|c|c|c|c|c|c|}
\hline \multicolumn{3}{|c|}{ Individual } & \multicolumn{2}{|c|}{ HLA A-B-C-D- Type } & \multicolumn{3}{|c|}{ Designation } \\
\hline & Father, W. M. & & $2,12,5$ & $32,14,-,-$ & & $\mathrm{A} / \mathrm{B}$ & \\
\hline & Mother, L. M. & & $2,12,5$ & $11,12-, \mathrm{Dw} 4$ & & $\mathrm{~A} / \mathrm{C}$ & \\
\hline & Child, M. M. & & $2,12,5$ & $2,12,5, \mathrm{Dw} 4$ & & $\mathrm{~A} / \mathrm{A}$ & \\
\hline & Child, B. M. & & $2,12,5$ & $2,12,5, \mathrm{Dw} 4$ & & $\mathrm{~A} / \mathrm{A}$ & \\
\hline & Child, P. M. & & $2,12,5$, & $32,14,-,-$ & & $\mathrm{A} / \mathrm{B}$ & \\
\hline & Child, J. M. & & $2,12,5$ & $32,14,-,-$ & & $\mathrm{A} / \mathrm{B}$ & \\
\hline & Child, T. M. & & $2,12,5$ & $32,14,-,-$ & & $\mathrm{A} / \mathrm{B}$ & \\
\hline \multicolumn{8}{|c|}{ Irradiated (stimulator) cells } \\
\hline Responder cells & W. M.* & L. M.* & M. M.* & B. M.* & P. M.* & J. M.* & T. M.* \\
\hline A/B W. M. & $1.2(0)$ & $4.8(5 \%)$ & $1.6(1 \%)$ & $2.2(1 \%)$ & $1.2(0)$ & $1.1(0)$ & $0.7(0)$ \\
\hline A/C L. M. & $46.3(70 \%)$ & $0.5(0)$ & $1.1(1 \%)$ & $1.3(1 \%)$ & $32.6(49 \%)$ & $29.8(45 \%)$ & $35.2(53 \%)$ \\
\hline A/A M. M. & $8.9(44 \%)$ & $2.8(0)$ & $7.2(0)$ & $4.0(0)$ & $9.2(53 \%)$ & $6.8(0)$ & $6.5(0)$ \\
\hline A/A B. M. & $39.9(61 \%)$ & $5.0(6 \%)$ & $1.1(0)$ & $0.9(0)$ & $46.1(71 \%)$ & $50.7(78 \%)$ & $42.0(64 \%)$ \\
\hline A/B P. M. & $0.4(0)$ & $4.5(1 \%)$ & $0.3(0)$ & $0.8(0)$ & $0.7(0)$ & $0.4(0)$ & $1.6(0)$ \\
\hline A/B J. M. & $1.6(0)$ & $0.5(0)$ & $0.2(0)$ & $1.2(0)$ & $0.5(0)$ & $0.6(0)$ & $0.4(0)$ \\
\hline $\mathrm{A} / \mathrm{B}$ T. M. & $1.8(0)$ & $3.6(1 \%)$ & $2.2(0)$ & $1.9(0)$ & $1.6(0)$ & $1.6(0)$ & $1.4(0)$ \\
\hline
\end{tabular}

The upper part of the table shows the HLA type of seven members of the family M. The lower part shows the MLR between family members as $\mathrm{cpm} \times 10^{-3}$ and as relative responses (in adjacent parentheses). The relative response was calculated according to the formula: Relative response $=$ (test cpm - low control cpm)/(high control cpm - low control cpm) $\times 100$. The low control was an autologous cell mixture and the high control was the median value of the five highest responses achieved against a random panel of 10 unrelated stimulators.

* Designates stimulator cells. 
shown by cross-testing with reference homozygous typing cells (10) to be homozygous for the specificity HLA-Dw4. M. M.'s father, W. M., and three siblings are HLA identical and heterozygous for the HLA-A and $B$ loci. They are also heterozygous for the Dw4 specificity as demonstrated by their failure to respond to Dw4 homozygous family members and their stimulation of these same members in the reverse reaction. The surprise finding is that $\mathbf{M}$. M. responds only weakly to his heterozygous relatives and in data to be shown later, M. M. fails repeatedly to respond, or responds only weakly, to the majority of a random panel of allogeneic cells. Interestingly, M. M.'s response to autologous cells tends to be higher than his responses to some allogeneic cells and higher than the autologous responses of others.

Quantitation of $T$ cells, B cells, and monocytes in $M . M$. initial studies to determine the distribution of peripheral blood $\mathrm{T}$ cells, $\mathrm{B}$ cells, and monocytes in $M$. M. indicate that although the absolute numbers of $\mathrm{T}$ cells and $\mathrm{B}$ cells are slightly below normal, their relative proportions are within normal limits (Table II). In addition, the levels of $\operatorname{IgG}, \operatorname{IgM}$, and IgA are within normal limits. Such data do not, of course, rule out the possibility that a functional subset of either $\mathrm{T}$ cells or B cells is reduced or increased.

Evidence that M. M.'s low responses to allogeneic cells are due to a suppressor cell. Possible explanations for M. M.'s weak responses in the MLR included a defective responder cell population, serum blocking factor such as an antibody which interfered with the MLR, or cellular suppression by $\mathrm{T}$ cells, B cells, or macrophages. Experiments similar to those used to test

TABLE II

Distribution of Mononuclear Leukocytes in M. M.

\begin{tabular}{|c|c|c|}
\hline & M. M. & Normal range \\
\hline Total leukocytes & 5,600 & $5,000-10,000 / \mathrm{mm}^{3}$ \\
\hline $\begin{array}{l}\text { Absolute T lymphocyte } \\
\text { count }\end{array}$ & $994, * 1,156 \ddagger$ & $1,200-2,500 / \mathrm{mm}^{3}$ \\
\hline $\begin{array}{l}\text { Absolute B (Ig+) lympho- } \\
\text { cyte count }\end{array}$ & 195 & $200-650 / \mathrm{mm}^{3}$ \\
\hline \multicolumn{3}{|l|}{$\begin{array}{l}\text { Distribution of Ficoll- } \\
\text { purified cells }\end{array}$} \\
\hline $\begin{array}{l}\text { Monocytes (by specific } \\
\text { strain) }\end{array}$ & $14 \%$ & $8-32 \%$ \\
\hline Lymphocytes & $86 \%$ & $68-92 \%$ \\
\hline \multicolumn{3}{|l|}{$\begin{array}{l}\text { Distribution of Ficoll- } \\
\text { purified lymphocytes }\end{array}$} \\
\hline $\operatorname{Ig}(+)$ lymphocytes & $11 \%$ & $10-30 \%$ \\
\hline Rosetting lymphocytes & $74 \%$ & $65-90 \%$ \\
\hline T cells by cytotoxicity & $86 \%$ & $65-90 \%$ \\
\hline
\end{tabular}

* By the sheep erythrocyte rosetting technique.

$\$$ By cytotoxicity with an anti-T cell antiserum.

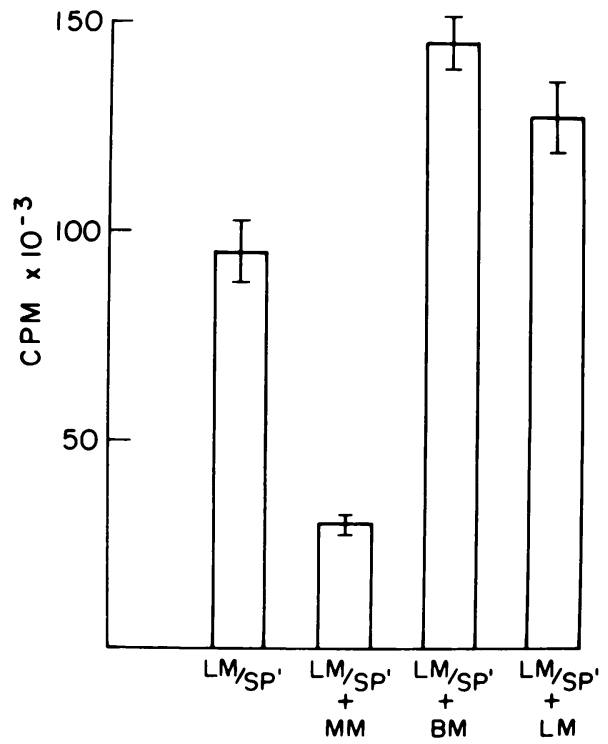

Figure 1 The effect of M. M. cells on the MLR between L. M. and S. P.' L. M. is HLA-B,D identical to M. M. (see Table I). S. P., the irradiated stimulator cell, is an HLA-A2,29/ B 12,21.1/C-/D 107,-individual selected at random from a panel of unrelated donor cells. Each column height represents the MLR response in counts per minute, with bars showing the standard error of the mean of six experiments. The first column depicts L. M.'s response to S.P.' The second column shows the same MLR in the presence of $50,000 \mathrm{M}$. M. cells. In the third column 50,000 cells from M. M.'s HLA identical sibling B. M. have been added to the MLR. In the fourth column 50,000 additional L. M. responder cells have been added for a total of 100,000 L. M. responders.

these possibilities in another individual (5) were carried out on M. M. A cellular explanation for his weak responses was supported by the observation that addition of M. M. lymphocytes markedly suppressed the MLR between cells from his $H L A-B, D$ identical relatives (B. M. or L. M.) and irradiated allogeneic stimulator cells (Fig. 1). That is, when $50,000 \mathrm{M}$. M. cells were mixed with $50,000 \mathrm{~B}$. M. or L. M. cells and challenged with 50,000 irradiated cells from an unrelated donor, S. P., the response was at least $50 \%$ below that obtained by culturing B. M. or L. M. alone with S. $P$. cells. Suppression was observed despite repeated washing of $\mathbf{M}$. M. cells and was unchanged if $\mathbf{M}$. M. cells cultured alone for $24 \mathrm{~h}$ (and washed again) were used (data not shown). Ordinarily, under the conditions of the MLR performed in this laboratory, an increase in the number of responder cells above 50,000 results in an increased response. Thus, a control MLR between B. M. and S. P. is augmented, not suppressed, by the addition of $50,000 \mathrm{~B}$. M. cells or $50,000 \mathrm{~L}$. M. cells.

Time-course of the suppressive effects of M. M. cells. The previously described experiments were all harvested after 7 days culture, the normal peak in the 
human MLR performed in microtiter wells in this laboratory. If the three-cell mixtures had accelerated kinetics, it is possible that the apparent suppression at day 7 might in fact be the descending curve of an earlier peak. A time-course experiment was, therefore, carried out to exclude this possibility. Replicate cultures were set up on day () and harvested on days 3-9. The results (Fig. 2) show that in the three-cell mixtures suppression was maximal at day 7 . The pattern of suppression is similar to that observed in another human MLR suppressor system (5) in that proliferation occurs unaffected until days $4-5$ at which time the level of $\left[{ }^{3} \mathrm{H}\right]$ thymidine incorporation begins to decline.

Evidence that the suppressor is a T cell. T and B cells from M. M. were separated as described in Methods, either on the basis of their differential affinity for anti-immunoglobulin antibody (method 1) or by the sheep cell rosetting technique (method 2). Preparations of T cells were 85-95\% pure as judged by rerosetting, and preparations of B cells consisted of 80-90\% nonrosetting cells. 50,000 T enriched cells or $\mathrm{B}$ enriched cells were tested for their ability to suppress the response of B. M. to an irradiated allogeneic lymphocyte, S. P. The results are shown in Fig. 3. As the results indicate, suppressor activity resides primarily in the $T$ cell fractions. The mild suppression seen with one $B$ cell preparation was probably due to contamination by $\mathrm{T}$ cells. Similarly prepared $\mathrm{T}$ cells from $\mathrm{B}$. M. or $\mathrm{L}$. $\mathrm{M}$. were not suppressive of the MLR.

Fig. 4 depicts the effects on the MLR of different numbers of M. M.'s T cells prepared by method 1 .

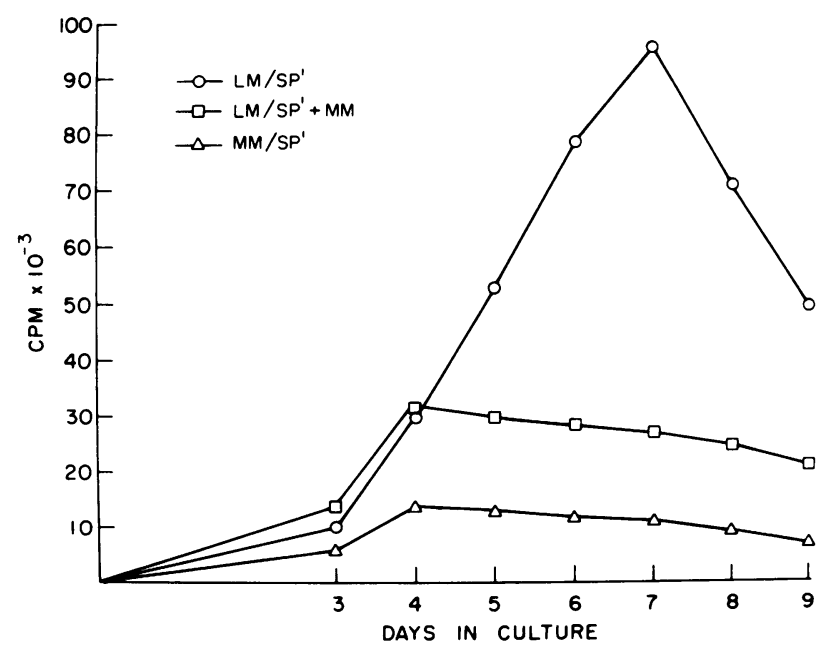

FIgURE 2 Time-course of suppression by M. M. of the MLR between L. M. and S. P.' MLR's between L. M. and S. P.', M. M. and S. P.', and L. M. and S. P.' with M. M. added were begun on day 0 and the reactions stopped on days 3-9. Each point represents the mean response of triplicate cultures.

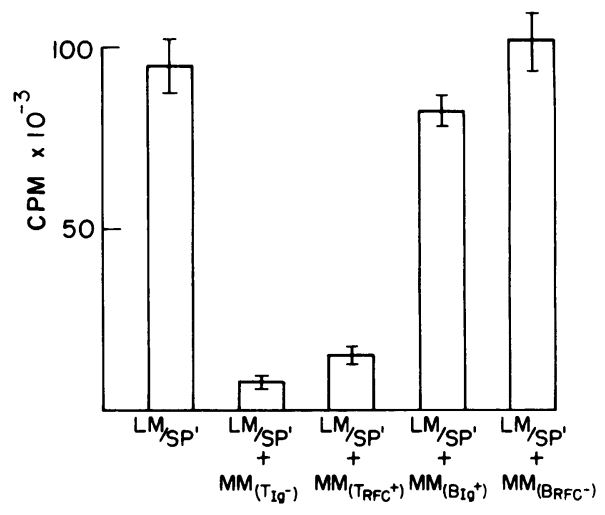

Figure 3 The effect of M. M.'s T cells compared to M. M.'s B cells on the MLR between L. M. and S. P.' M. M.'s T cells were separated from his B cells either by a technique in which B cells remained bound to immunoglobulin coated on a plastic surface $\left(\mathrm{B}_{\mathrm{Ig}+}\right)$ and $\mathrm{T}$ cells eluted $\left(\mathrm{T}_{\mathrm{Ig}-}\right)$ or by a technique in which rosette forming cells $\left(\mathrm{T}_{\mathrm{RFC}+}\right)$ were separated from $\mathrm{B}$ cells $\left(\mathrm{B}_{\mathrm{RFC}-}\right)$ on a Ficoll-Hypaque gradient. 50,000 $\mathrm{T}$ cells prepared by each technique, and $50,000 \mathrm{~B}$ cells prepared by each technique were co-cultured in the MLR L. M./S. P.' Each bar represents the mean of sextuplicate cultures.

Although the numbers of $\mathrm{L}$. M. responder cells and S. P. stimulator cells were held constant at 50,000 each, as few as $5,000 \mathrm{M}$. M. T cells had a detectable inhibitory effect on L. M.'s response. The potency of suppression increased as a function of the number of M. M. T cells in the reaction. Maximal suppression was achieved with $50,000 \mathrm{M}$. M. T cells.

Failure of M. M. to inhibit PHA or Con A stimulation. 100,000 cells from M. M. or controls (B. M., L. M., or an unrelated donor, S. P.) were incubated for 4 days with PHA or Con A as described in Methods. The range of response by controls to PHA was $82,704 \pm 6,425-116,091 \pm 9,441$ and to Con A $34,918 \pm 1,984-48,122 \pm 3,712$. M. M.'s responses to PHA $(104,961 \pm 10,209)$ and Con A $(46,403 \pm 2,342)$ were well within the range of control responses. Furthermore, the addition of $100,000 \mathrm{M}$. M. cells to B. M. or L. M. enhanced the responses of these cells to both mitogens by at least $50 \%$. Increases of similar magnitude were obtained when $100,000 \mathrm{~B}$. M. cells were added to $\mathrm{L}$. M. or M. M. Thus, M. M. responds normally to PHA and Con A and does not inhibit the responses of other cells to these mitogens.

Effect of $M$. M. on the proliferative response to soluble antigens. 100,000 or 200,000 cells from five subjects including M. M. and L. M., and unrelated controls were incubated with tetanus toxoid and diphtheria toxoid as described in the Methods, using doses of antigen found previously to elicit maximum in vitro stimulation in normal controls. All five subjects had been immunized with these antigens in 1975, as part of prior studies. At that time a wide range of responses was found among these five individuals, but 


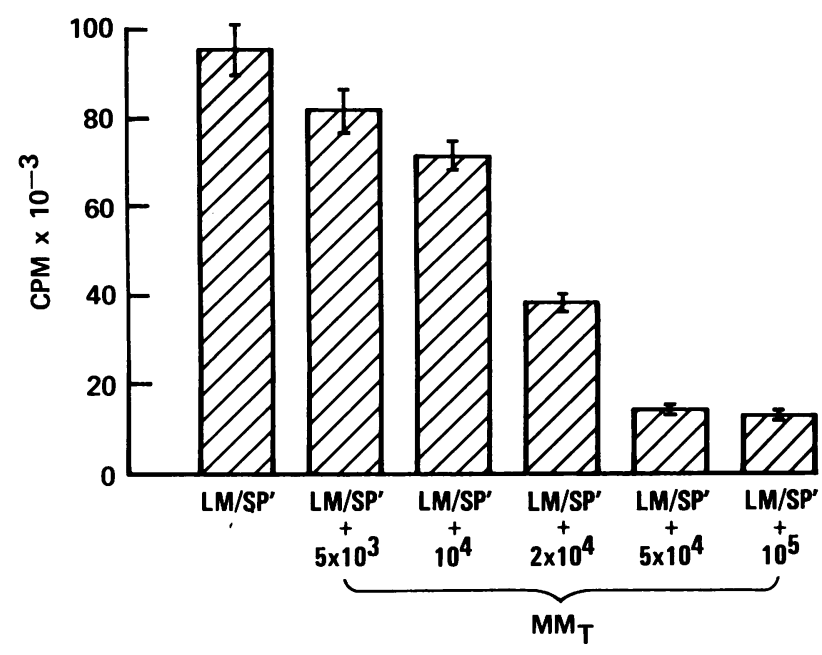

FIGURE 4 The effect of increasing the concentration of $\mathbf{M}$. M. T cells on the MLR between L. M. and S. P.' M. M.'s T cells were separated from his B cells on the basis of their lack of affinity for anti-Ig coated on a plastic surface. Different numbers of $T$ cells ranging from 5,000 to 100,000 were co-cultured in the MLR L. M./S. P.' Each bar represents the mean of sextuplicate cultures.

all five were considered to respond positively to both antigens (11). They have not been reimmunized.

The current responses of M. M. and L. M. to tetanus and diphtheria toxoids are shown in Table III. The responses of $100,000 \mathrm{M}$. M. cells to tetanus toxoid $(30,786 \pm 1,980 \mathrm{cpm})$ and diphtheria toxoid $(14,614$ $\pm 994)$ were within the range of responses to these antigens by normal controls. The responses of 100,000 L. M. cells were $48,873 \pm 2,712$ and $8,352 \pm 519$ to tetanus and diphtheria toxoids, respectively, and these responses increased when $200,000 \mathrm{~L}$. M. cells were tested. The addition of $100,000 \mathrm{M}$. M. cells to 100,000 L. M. cells resulted in responses of $32,802 \pm 3,977$ to tetanus toxoid, and $15,098 \pm 1,112$ to diphtheria toxoid.
Thus, although M. M. responds normally to tetanus toxoid, he inhibits L. M.'s response to this antigen by $33 \%$. He fails to inhibit L. M.'s relatively weak response to diphtheria toxoid.

Evidence that M. M. cells are not killer cells. It is theoretically possible that M. M. T lymphocytes kill either allogeneic stimulator cells or syngeneic responder cells, with resultant reduction of the MLR. M. M. cells were, therefore, mixed with ${ }^{51} \mathrm{Cr}$ labeled S. P. or L. M. lymphocytes under conditions of the lymphocyte-mediated antibody-dependent cytotoxicity assay. The experimental conditions of this assay are very close to those of the MLR culture, the antibody being $10 \%$ pooled, heat-inactivated human serum. The background controls of target cells incubated for $4 \mathrm{~h}$ with effector lymphocytes in the absence of human serum or with serum in the absence of effector cells never exceeded $5 \%$ for either S. P. or L. M. At a killer (M. M.) to target (S. P. or L. M.) ratio of 20:1 and after $4 \mathrm{~h}$ incubation, the percent ${ }^{51} \mathrm{Cr}$ release from target cells was $4.9 \%$ for S. P. target cells and $2.4 \%$ for the L. M. target cells (background release subtracted). Neither of these values differed significantly from results obtained when cells other than M. M. were tested as effectors. A positive control serum with known anti-HLA-B12 cytotoxic antibody resulted in $39 \%{ }^{51} \mathrm{Cr}$ release when S. P. was the target and $34 \%$ ${ }^{51} \mathrm{Cr}$ release when $\mathrm{L}$. M. was the target.

Specificity of the suppressor $T$ cell for the responder cell in the MLR. The ability of M. M. to suppress the responses of his first degree relatives to the stimulator cells from a single unrelated donor (S. P.) are summarized in Table IV. M. M.'s suppression of a panel of 18 unrelated responders challenged by the same allogeneic stimulator are shown in Table V. It is apparent from both tables that only those responders homozygous or heterozygous for HLA-Dw4 were suppressed regardless of the associated HLA-A, B, or C

TABLE III

Effect of M. M. on the Responses to Tetanus and Diphtheria Toxoids

\begin{tabular}{|c|c|c|c|c|c|c|c|}
\hline & \multicolumn{4}{|c|}{ Responder cell $\left(10^{5}\right.$ cells $)$} & \multirow{2}{*}{$\begin{array}{l}\text { Second } \\
\text { party cell } \\
\text { (10 cells) }\end{array}$} & \multicolumn{2}{|c|}{ Response $\pm \mathrm{SE}$} \\
\hline & A & B & $\mathrm{Cw}$ & Dw & & $\begin{array}{l}\text { Tetanus } \\
\text { toxoid }\end{array}$ & $\begin{array}{l}\text { Diphtheria } \\
\text { toxoid }\end{array}$ \\
\hline M. M. & 2,2 & 12,12 & 5,5 & 4,4 & M. M. & $\begin{array}{l}30,786 \pm 1,980 \\
37,915 \pm 2,360\end{array}$ & $\begin{array}{l}14,614 \pm 994 \\
19,205 \pm 1,940\end{array}$ \\
\hline L. M. & 2,2 & 12,12 & $5,-$ & 5,5 & $\begin{array}{l}-\overline{\text { L. M. }} \\
\text { M. M. }\end{array}$ & $\begin{array}{l}48,873 \pm 2,712 \\
58,427 \pm 3,054 \\
32,802 \pm 3,977\end{array}$ & $\begin{array}{c}8,352 \pm 519 \\
11,966 \pm 880 \\
15,098 \pm 1,112\end{array}$ \\
\hline Cont & & & & & - & range $(20,420-56,019)$ & range $(6,054-44,212)$ \\
\hline
\end{tabular}

Each row describes a 7 -day culture between 100,000 or 200,000 responder cells and either tetanus or diphtheria toxoid (see Methods for antigen doses). The response in counts per minute $\pm \mathrm{SE}$ represents the mean of six experiments. 
TABLE IV

Effect of M. M. on the Responses of M Family Members to an Allogeneic Cell

\begin{tabular}{|c|c|c|c|c|c|c|c|c|}
\hline & & Respo & & & & & & \\
\hline & A & B & $\mathrm{Cw}$ & $\overline{D w}$ & $\begin{array}{l}\text { Third } \\
\text { party cell }\end{array}$ & Response $\pm \mathrm{SE}$ & Change & $P$ value \\
\hline & & & & & & & $\%$ & \\
\hline M. M. & 2,2 & 12,12 & 5,5 & 4,4 & - & $11,122 \pm 1,652$ & - & \\
\hline L. M. & 2,11 & 12,12 & $5,-$ & 4,4 & $\begin{array}{l}- \\
\text { M. M. } \\
\text { B. M. }\end{array}$ & $\begin{array}{r}95,460 \pm 5,824 \\
29,202 \pm 2,190 \\
144,798 \pm 7,153\end{array}$ & $\begin{array}{l}-\overline{-} \\
+69.4 \\
+51.8\end{array}$ & $<0.001$ \\
\hline W. M. & 2,14 & 12,32 & $5,-$ & $4,-$ & $\begin{array}{l}\text { M. M. } \\
\text { B. M. }\end{array}$ & $\begin{array}{r}76,356 \pm 5,219 \\
64,250 \pm 3,868 \\
129,058 \pm 9,615\end{array}$ & $\begin{array}{l}-\overline{-} \\
-69.8 \\
+69.0\end{array}$ & $<0.05$ \\
\hline B. M. & 2,2 & 12,12 & $5,-$ & 4,4 & $\overline{M .} \mathrm{M}$. & $\begin{array}{l}61,130 \pm 6,530 \\
26,384 \pm 3,955\end{array}$ & $-\overline{-56.8}$ & $<0.001$ \\
\hline P. M. & 2,14 & 12,32 & $5,-$ & $4,-$ & $\begin{array}{l}\overline{-} \\
\text { M. M. } \\
\text { B. M. }\end{array}$ & $\begin{array}{l}51,540 \pm 4,310 \\
42,417 \pm 2,756 \\
97,633 \pm 6,820\end{array}$ & $\begin{array}{l}-\overline{17} .6 \\
+89.6\end{array}$ & $<0.05$ \\
\hline J. M. & 2,14 & 12,32 & $5,-$ & $4,-$ & M. M. & $\begin{array}{l}55,427 \pm 3,425 \\
50,824 \pm 567\end{array}$ & $-\overline{-8.3}$ & $>0.05$ \\
\hline
\end{tabular}

Each row describes a 7-day MLR between 50,000 irradiated stimulator cells and 50,000 unirradiated responder cells with or without 50,000 unirradiated cells from a third party, either M. M. or his HLA identical sibling B. M. The same stimulator cell from an unrelated donor, SP (A3,29/B12,21,1/C-/D107-), was used in each reaction. The response in counts per minute \pm standard error represents the mean of six experiments. The $P$ value was determined by the two-tailed $t$ test.

antigens. All of the Dw4 homozygous cells and all but one Dw4 heterozygous cell were significantly suppressed by M. M. In general, the degree of suppression was greater on Dw4 homozygous cells than heterozy- gous cells. The responses of non-Dw4 cells were uniformly enhanced by the addition of M. M.

Radiosensitivity of the M. M. suppressor cell. As shown in Fig. 5, the M. M. suppressor T cell resists a

TABLE V

The M. M. Suppressor Cell: Specificity for HLA-Dw4 in Unrelated Responders*

\begin{tabular}{|c|c|c|c|c|c|c|c|}
\hline & \multicolumn{4}{|c|}{ Responder HLA type } & \multicolumn{2}{|c|}{ Response to SP } & \multirow[b]{2}{*}{ Change } \\
\hline & A & B & $\mathrm{C}$ & D & Without M. M. & With M. M. & \\
\hline & & & & & & & $\%$ \\
\hline M. C. & 2,2 & 12,12 & & 4,4 & $63,612 \pm 3,153$ & $26,260 \pm 1,588$ & $-58.6^{* *}$ \\
\hline I. N. & $3,-$ & $15,-$ & & $4,-$ & $48,428 \pm 2,100$ & $29,646 \pm 1,650$ & $-38.8^{* *}$ \\
\hline E. G. & 3,30 & 7,15 & & 2,4 & $89,254 \pm 4,675$ & $34,905 \pm 2,984$ & $-60.5^{* *}$ \\
\hline D. B. & 9,14 & 12,32 & & $4,-$ & $94,110 \pm 6,571$ & $67,426 \pm 7,212$ & $-28.3^{* *}$ \\
\hline S. F. & 2,24 & 13,27 & $2,-$ & $4,-$ & $105,669 \pm 5,247$ & $62,433 \pm 8,520$ & $-40.9 * *$ \\
\hline W. H. & 11,28 & 35,35 & $\mathrm{~T} 7,-$ & 1,1 & $45,509 \pm 3,218$ & $72,430 \pm 1,061$ & +74.4 \\
\hline L. H. & 3,3 & 7,7 & 1, & 2,2 & $44,622 \pm 5,814$ & $67,911 \pm 7,012$ & +52.2 \\
\hline J. B. & 1,1 & 8,8 & & 3,3 & $91,388 \pm 8,270$ & $111,749 \pm 7,461$ & +22.3 \\
\hline M. H. & 2,29 & 12,27 & 1, & 1,107 & $29,639 \pm 3,120$ & $53,150 \pm 6,336$ & +79.6 \\
\hline W. B. & 3,29 & 7,12 & & $2,-$ & $69,543 \pm 7,684$ & $100,228 \pm 8,019$ & +44.1 \\
\hline D. $S$. & 2,3 & 14,40 & $\mathrm{~T} 7$ & $5,-$ & $86,492 \pm 3,840$ & $104,346 \pm 6,592$ & +20.6 \\
\hline B. C. & 1,29 & 17,35 & $4, \mathrm{~T} 7$ & $6,-$ & $56,411 \pm 4,703$ & $82,970 \pm 9,645$ & +47.1 \\
\hline M. I. & 2,32 & 12,35 & 4,5 & $107,-$ & $75,773 \pm 6,883$ & $103,854 \pm 8,590$ & +37.1 \\
\hline
\end{tabular}

* Each row describes a 7-day MLR between 50,000 irradiated stimulator cells and 50,000 responder cells with or without 50,000 M. M. cells. The same stimulator cell from an unrelated donor, S. P. (A3,29/B12,21,1/C-/D107-) was used in each reaction. The response in counts per minute \pm standard error represents the mean of six experiments.

f Suppression by M. M. significant at $P<0.001$ by the two-tailed t test. 

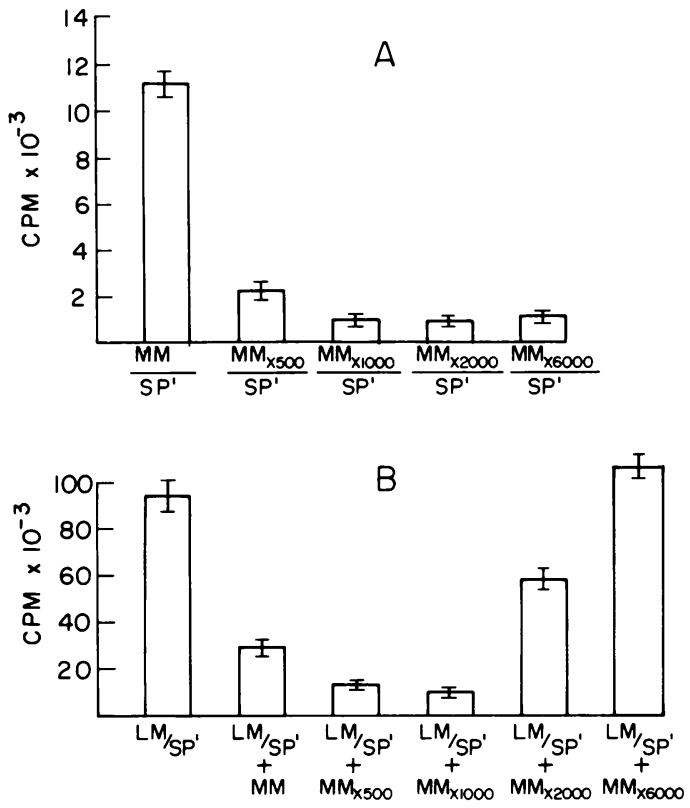

FIGURE 5 The sensitivity of M. M. responder cells and M. M. suppressor cells to $\gamma$-irradiation. (A), Demonstrates the sensitivity of M. M. responder cells to increasing of $\gamma$-irradiation as measured in one-way MLR's between 50,000 M. M. cells and 50,000 irradiated $(6,000$ rads) cells from an allogeneic donor $\mathrm{S}$. P. The responses represent the mean of six experiments at each radiation level. (B), Shows the sensitivity of M. M. suppressor cells to increasing doses of $\gamma$-irradiation, as measured by the ability of $50,000 \mathrm{M}$. M. cells to inhibit the MLR between L. M. and S. P.'

dose of $\gamma$-irradiation which functionally eliminates M. M. responder cells. Thus, M. M.'s weak responses to allogeneic cells were eliminated with 1,000 rads. In contrast, the M. M. suppressor cell function remained intact after $1,000 \mathrm{rads}$, was partially eliminated by 2,000 rads, and completely eliminated by 6,000 rads.

When M. M. lymphocytes were irradiated with 1,000 rads $\left(\mathbf{M} . \mathbf{M}_{\times_{\mathbf{1}, 000}}\right)$ and tested on a panel of responder cells of varied haplotype, the pattern of suppression remained the same as with unirradiated $\mathbf{M}$. M. (Table VI). That is, only cells possessing the Dw4 specificity were significantly inhibited in the MLR. The magnitude of suppression by $\mathbf{M} . \mathbf{M}_{\times \times 1,000}$ of cells heterozygous for Dw4 has increased, however, presumably due to elimination of M. M.'s response to the non-Dw4 haplotype. Furthermore, addition of $\mathbf{M}$ M. $_{\times_{1,000}}$ (but not M. M.) inhibited M. M.'s autologous response by $57 \%$ from $7,240 \pm 610$ to $3,110 \pm 360$ ), (significant at $P<0.01$ by the two-tailed $t$ test.)

When M. M. lymphocytes were irradiated with 6,000 rads $\left(\mathbf{M} . \mathbf{M}_{\times \mathbf{1}, 000}\right)$ and tested on the same panel of responder cells, there was no suppression (Table VI). Of added significance is the fact that the MLR responses of non-Dw4 cells were in general, no greater in the presence of $M . M_{\times 6,000}$ than $M . M \cdot \times_{1,000}$, confirming that non-Dw4 cells are not suppressed by $\mathbf{M} . \mathbf{M} \cdot \times_{1,000}$.

Lack of specificity of the M. M. suppressor cell for the stimulating cell in the MLR. The responses of M. M. to cells homozyous for different HLA-D antigens as well as to a random panel of allogeneic stimulator cells are shown in Table VII. M. M. responded only weakly to the great majority of these cells. When L. M. was tested as a responder to these same cells (Table VII), her responses were much greater and are typical of allogeneic responses in the MLR. Addition of 50,000 M. M. cells to these latter reactions between L. M. and a panel of allogeneic stimulator cells resulted in at least $50 \%$ inhibition of 14 of 17 reactions. The reactions not suppressed were those in which an irradiated allogeneic cell stimulated a response in M. M. When these allogeneic reactions on the part of $\mathbf{M}$. M. were eliminated with $1,000 \mathrm{rads}, \mathrm{M}$. M. $\mathbf{\times 1}_{\mathbf{1}, 000}$ inhibited the responses of L. M. to all 17 stimulator cells. Thus, although the M. M. suppressor cell is specific for $H L A-D$ in the responder, it is non-specific with respect to the haplotype of the stimulator cell.

TABLE VI

Sensitivity of the M. M. Suppressor Cell to X-Irradiation

\begin{tabular}{|c|c|c|c|c|}
\hline \multicolumn{2}{|c|}{ Responder } & \multicolumn{3}{|c|}{$\begin{array}{c}\text { Change of response to an allogeneic cell S. P } \\
\text { after addition }\end{array}$} \\
\hline Family & HLA-D & M. M. & M. M. $\times 1.000$ & M. M. $\times 6.000$ \\
\hline L. M. & $4 / 4$ & $-69.4 \%$ & $-89.2 \%$ & $+16.2 \%$ \\
\hline W. M. & $4 /-$ & -15.8 & -.54 .3 & +9.4 \\
\hline B. M. & $4 / 4$ & -56.8 & -78.9 & +22.5 \\
\hline P. M. & $4 /-$ & -17.6 & -60.1 & +2.2 \\
\hline J. M. & $4 /-$ & -8.3 & -.58 .3 & +7.8 \\
\hline \multicolumn{5}{|c|}{ Unrelated donors Dw4+ } \\
\hline M. C. & $4 / 4$ & -58.6 & -80.3 & +5.9 \\
\hline I. N. & $4 /-$ & -38.8 & -68.5 & +12.6 \\
\hline E. G. & $4 / 2$ & -60.5 & -62.5 & -4.7 \\
\hline D. B. & $4 /-$ & -28.3 & $-44 .()$ & +15.2 \\
\hline S. F. & $4 / 6$ & -40.9 & -51.4 & +12.4 \\
\hline \multicolumn{5}{|c|}{ Unrelated donors Dw4- } \\
\hline W. H. & $1 / 1$ & +74.4 & +30.8 & +36.7 \\
\hline L. H. & $2 / 2$ & +18.9 & +32.6 & +9.6 \\
\hline J. B. & $3 / 3$ & +22.3 & +24.4 & +9.9 \\
\hline M. H. & $1 / 107$ & +79.6 & +46.2 & +49.4 \\
\hline W. B. & $2 /-$ & +44.1 & +30.7 & +24.1 \\
\hline D. S. & $5 /-$ & +20.6 & +10.4 & +22.2 \\
\hline B. C. & $6 /-$ & +47.1 & +33.6 & +25.8 \\
\hline M. I. & $107 /-$ & +37.1 & +26.5 & +20.9 \\
\hline
\end{tabular}

Each row represents the effect of M. M. either unirradiated or exposed to 1,000 or $6,000 \mathrm{rads}$, on the MLR's between a panel of responders and the irradiated stimulator, $S$. P. The complete HLA phenotypes of responders and their responses to $S$. P. in the absence of M. M. are shown in Table VI. 
Effect of M. M. on L. M.'s Response to a Variety of Stimulator Haplotypes

\begin{tabular}{|c|c|c|c|c|c|c|c|c|c|c|}
\hline \multirow[b]{2}{*}{ HLA } & \multicolumn{4}{|c|}{ Stimulating cell } & \multicolumn{6}{|c|}{ MLR response $(\mathrm{CPM} \pm \mathrm{SE})$} \\
\hline & A & B & $\mathrm{C}$ & D & L. M. & M. M. & L. M. + M. M. & $\begin{array}{l}\text { Change } \\
\text { of cpm }\end{array}$ & L. M. $+M_{1} M_{\times \times 1,000}$ & $\begin{array}{l}\text { Change } \\
\text { of cpm }\end{array}$ \\
\hline & & & & & & & & $\%$ & & $\%$ \\
\hline W. H. & 11,28 & 35,35 & $\mathrm{~T} 7$ & 1,1 & $88,582 \pm 7,577$ & $8,217 \pm 1,070$ & $38,822 \pm 4,589$ & -56.2 & $16,612 \pm 1,056$ & -81.2 \\
\hline C. L. & 2,3 & 7,7 & & 2,2 & $53,000 \pm 5,393$ & $8,448 \pm 730$ & $25,140 \pm 3,441$ & -52.6 & $12,172 \pm 1,017$ & -77.0 \\
\hline J. B. & 1,1 & 8,8 & & 3,3 & $59,717 \pm 5,177$ & $10,777 \pm 1,469$ & $15,248 \pm 1,031$ & -74.5 & $12,965 \pm 2,703$ & -78.3 \\
\hline J. B. & 32,32 & 16,16 & & 5,5 & $55,666 \pm 7,372$ & $23,259 \pm 837$ & $40,127 \pm 4,556$ & -17.9 & $9,052 \pm 1,818$ & -83.7 \\
\hline M. A. & 1,2 & 17,17 & & 17,17 & $46,412 \pm 7,628$ & $4,469 \pm 1,015$ & $16,856 \pm 1,074$ & -63.7 & $12,886 \pm 1,954$ & -72.2 \\
\hline M. H. & 2,29 & 12,27 & 1 & 1,107 & $68,822 \pm 6,947$ & $6,588 \pm 614$ & $24,058 \pm 2,992$ & -65.0 & $17,802 \pm 2,520$ & -74.1 \\
\hline W. B. & 3,29 & 7,12 & & $2,-$ & $114,309 \pm 7,839$ & $12,776 \pm 1,869$ & $42,263 \pm 6,879$ & -63.0 & $24,128 \pm 3,218$ & -98.9 \\
\hline W. M. & 2,14 & 12,32 & 5 & $4,-$ & $49,031 \pm 3,349$ & $16,450 \pm 1,775$ & $45,677 \pm 6,649$ & -6.8 & $16,044 \pm 1,104$ & -67.3 \\
\hline E. G. & 3,30 & 7,15 & & 2,4 & $88,925 \pm 10,746$ & $12,992 \pm 472$ & $29,783 \pm 1,393$ & -76.5 & $15,922 \pm 1,641$ & -82.1 \\
\hline D. B. & 9,14 & 12,32 & & $4,-$ & $59,479 \pm 8,633$ & $6,374 \pm 1,096$ & $20,534 \pm 6,619$ & -65.5 & $9,642 \pm 1,704$ & -83.8 \\
\hline S. F. & 2,24 & 13,27 & 2 & $4,-$ & $22,252 \pm 1,624$ & $1,841 \pm 370$ & $12,018 \pm 2,144$ & -46.0 & $2,069 \pm 1,751$ & -90.7 \\
\hline D. $S$. & 2,3 & 14,40 & $\mathrm{~T} 7$ & $5,-$ & $103,061 \pm 9,248$ & $6,634 \pm 1,614$ & $30.503 \pm 3,748$ & -70.4 & $12,407 \pm 1,538$ & -88.0 \\
\hline B. C. & 1,29 & 17,35 & $\mathrm{~T} 7$ & $6,-$ & $78,296 \pm 6,706$ & $11,603 \pm 2,627$ & $19,550 \pm 2,411$ & -75.0 & $7,186 \pm 1,564$ & -90.8 \\
\hline M. I. & 2,32 & 12,35 & 4 & $107,-$ & $61,681 \pm 5,535$ & $40,515 \pm 5,682$ & $61,769 \pm 4,278$ & +0.1 & $23,713 \pm 2,540$ & -61.6 \\
\hline C. $\mathrm{O}$. & 1,2 & 13,40 & 2 &,-- & $100,993 \pm 8,584$ & $15,238 \pm 2,988$ & $23,925 \pm 2,252$ & -76.3 & $15,528 \pm 1,909$ & -84.6 \\
\hline L. $S$. & 2,30 & 15,39 & &,-- & $93,276 \pm 9,800$ & $8,631 \pm 1,961$ & $35,754 \pm 3,025$ & -61.7 & $21,117 \pm 981$ & -77.4 \\
\hline E. E. & 2,24 & 38,38 & &,-- & $70,968 \pm 5,059$ & $7,076 \pm 665$ & $28,061 \pm 4,467$ & -60.0 & $17,021 \pm 2,859$ & -76.0 \\
\hline
\end{tabular}

\section{DISCUSSION}

These studies have demonstrated the presence of a suppressor $\mathrm{T}$ cell of the mixed lymphocyte reaction in a 23-yr-old man, M. M. The possibility that this cell is actually a killer cell cannot be completely excluded, but no evidence of killing by M. M. could be detected in a cell-mediated, antibody-dependent cytotoxicity assay. Another possibility, that suppression is mediated simply by an increase in cell density caused by adding $M$. M. cells to the culture, is argued against by several lines of evidence. First, the conditions of the MLR are such that any increase in syngeneic responder cells results in an increased proliferative response. Such increases were seen, for example, when the number of L. M. or B. M. responder cells were doubled to 100,000 or when $50,000 \mathrm{~B}$. M. cells were added to $50,000 \mathrm{~L}$. M. cells in an MLR. In contrast, as few as 5,000-10,000 M. M. T cells caused measurable suppression of the MLR. Secondly, suppression of the MLR by M. M. was retained when his cells were exposed to 1,000 rads but lost after exposure to $6,000 \mathrm{rads}$ of $\gamma$-irradiation. This would suggest that although proliferation of the suppressor cell may not be necessary for its inhibitory effects, active metabolism on the part of the suppressor cell is necessary.

Finally, M. M. only suppressed the MLRs of individuals who, like M. M., were HLA-Dw4 positive. The responses of Dw4 negative responder cells were uniformly enhanced by the addition of M. M. We considered the possibility that $M$. M. inhibits the responses of non-Dw4 cells in the MLR but that suppression is masked by the response of these cells to $M$. M., also present in the cultures. If this were true, the responses by non-Dw4 cells to allogeneic cells would have been greater in the presence of $M$. $_{\times_{\times 6,000}}$ than $M$. $M_{\cdot \times \mathbf{1}, 000}$. However, the reverse was found; the MLR responses of seven of eight non-Dw4 responders were greater in the presence of $\mathbf{M} . \mathbf{M}_{\times_{\mathbf{1}, 000}}$ than $\mathbf{M} . \mathbf{M}_{\times \mathbf{6}, \mathbf{0 0 0}}$. Thus, the M. M. suppressor T cell appears to be specific for $\mathrm{Dw}_{4} 4$ positive responder cells.

The demonstration of an $H L A-D$ restriction between $M$. M. and responders was made possible by a series of unusual circumstances. First, M. M. comes from a large family, two of whom share identity with him at $H L A-B$ and $D$, and respond normally in the MLR. These two individuals, B. M. and L. M., were ideal controls for these experiments. Second, M. M. is homozygous for a common HLA-D specificity, Dw4, which is not in strong linkage disequilibrium with HLA-A, and B, or C antigens. Therefore, unrelated persons who had only one antigen in common with $\mathrm{M}$. M. (for example, HLA-B12, or Dw4) were not difficult to find. Third, M. M. responded weakly to such a variety of allogeneic cells that addition of his cells to an MLR between two other individuals did not add significantly to the response.

The M. M. suppressor $T$ cell is similar to an MLR suppressor $\mathrm{T}$ cell described by Rich and Rich $(12,13)$ in the mouse, in that it lacks specificity for the stimulating 
haplotype but is highly specific for the responder cell. In the murine system, a factor released by MLR suppressor cells only inhibits the response of cells sharing the same $I-C$ subregion within the immune response region of the mouse major histocompatibility complex $(H-2)$. In the case of $\mathbf{M}$. M., the restriction appears to be localized to or near the HLA-D locus. In the absence of an available family with a crossover between HLA-B and HLA-Dw4, localization to the HLA-D end of HLA must remain tentative. Nonetheless, on the basis of current data it is inferred that genes in the $H L A-D$ region code for structures, presumably on $\mathrm{T}$ cells, which are recognized by MLR suppressor $\mathrm{T}$ cells as well as for determinants primarily on $B$ cells (the so-called Ia antigens) which are recognized by MLR responder cells $(14,4)$. In the mouse, genes responsible for similar functions have been mapped to the immune response region in the major histocompatibility complex $(12,15,16)$, a region which influences a remarkable array of immunologic functions (17). An immune response region is widely presumed to exist in man $(18-20)$ and although proof of such a region's existence is lacking, the current data are consistent with the hypothesis that $H L A-D$ may be the immune response region in man.

The fact that M. M. is the only member of his family to have received thymic irradiation may suggest that this treatment and M. M.'s MLR suppressor T cell phenomenon are causally related. In this regard, animal studies have demonstrated that the thymus is extremely radiosensitive (21). Furthermore, recovery from thymic irradiation has been associated with a diminished capacity to reject skin grafts or produce antibody against $\mathrm{T}$ cell-dependent antigens, despite normal numbers of peripheral lymphocytes (22). In man, irradiation of the thymus was once used to treat conditions such as neonatal respiratory distress that were inappropriately attributed to alleged thymic enlargement. This form of treatment was abandoned in the 1950's after an increased incidence of thyroid cancer was first noted to follow $\mathrm{x}$-irradiation to the neck and mediastinum (23). Adverse effects of such treatment on the immune system have been reported to include chromosomal aberrations in peripheral blood lymphocytes (24), a reduction of B and T lymphocytes, and a decreased mitogenic response of lymphocytes to mitogens in such patients as compared with controls (25). However, such changes were not found in another reported series (26). Clearly, M. M. retained considerable thymic function after his radiation treatment because his lymphocytes proliferate vigorously to the mitogens PHA and Con A as well as to tetanus toxoid, and he has only slightly depressed levels of $\mathrm{T}$ cells and $\mathrm{B}$ cells in his peripheral blood. Therefore, a definitive conclusion regarding the role of thymic irradiation in the case of M. M. must await a search for suppressor cells in other patients who received such treatment.

Although only HLA-Dw4 responder cells were inhibited by the M. M. suppressor T cell, Dw4 cells were inhibited in their responses to all stimulator cells tested, regardless of the stimulator's HLA type. This result is consistent with the possibility that $M$. M. has been sensitized to an antigen which either cross-reacts with or is common to a great many cells. Alternatively, M. M. may have been sensitized to his own cells, resulting in suppressor cells directed against his own HLA-Dw4 products. This hypothesis is supported by the observation that M. M.'s relatively high autologous response is inhibited by the addition of $\mathbf{M}$. M. $\mathbf{X}_{1,000}$ suppressor cells. Furthermore, M. M. has no history of exposure to allogeneic cells, to which a specific immune response might be expected. In contrast, a recently reported stimulator-specific MLR suppressor cell arose in a mother of 10 who specifically suppressed responses of HLA identical persons to her husband's cells, presumably as a result of repeated immunization with cells bearing his HLA antigens during pregnancy (5).

Nonspecific low responsiveness in the MLR, though hardly frequent enough to render the MLR a useless test, is nonetheless not a rare event. Both persons so far studied in this laboratory who are unresponsive to allogeneic cells, possess a T suppressor cell of the MLR. It is possible therefore, that suppressor $\mathrm{T}$ cells are responsible for most unexpected nonresponsiveness in the mixed lymphocyte reaction. In addition, the possibility exists that self-tolerance with respect to the MLR (that is, true typing responses) might be due to suppressor $\mathrm{T}$ cells.

Both individuals in whom genetically restricted MLR suppressor $\mathrm{T}$ cells have been reported are healthy, which may suggest that such cells are a normal immunoregulatory component. However, suppressor T cells other than MLR suppressor cells have been demonstrated in vitro in patients with such disorders as common variable hypogammaglobulinemia (27) and chronic fungal infections (28). Moreover, if the recognition of transformed cells is a function of alloreactive $T$ cells, susceptibility to malignancy might be increased in persons with MLR suppressor cells. In this regard, cellular suppression of the MLR has been reported in patients with Hodgkin's disease (29) and preliminary results suggest the presence of genetically restricted MLR suppressor cells in this disorder. ${ }^{2}$ Conversely, it is possible that possession of such cells might, under certain circumstances, be a desirable state. For example, they might protect against transplant rejection or

\footnotetext{
${ }^{2}$ Engleman, E. G., R. Hoppe, H. Kaplan, and H. O. McDevitt. Unpublished data.
} 
autoimmune reactions. These possibilities are currently being studied.

\section{ACKNOWLEDMENTS}

We thank Marion Batey for excellent technical assistance, Dr. F. C. Grumet for HLA-A, B, and C typing of the M family, Dr. Rose Payne for HLA-A, B, and C typing our panel of allogeneic cells, Glenda Garrelts for performing the assays for T cells, B cells, and monocytes on M. M. We also thank Drs. Daniel Meruelo, Peter Goodfellow, and Andrew McMichael for their review of this manuscript. We are especially grateful to the entire $\mathrm{M}$ family who gave of their blood and time repeatedly and without hesitation.

This work was supported by a grant from the Kroc Foundation (Santa Ynez, Calif.) and a grant from the National Institutes of Health (AI 11313).

\section{REFERENCES}

1. Benacerraf, B., and H. O. McDevitt. 1972. Histocompatibility linked immune response genes. Science (Wash. D. C.). 175: 273-279.

2. Klein, J. 1975. Biology of the Mouse Histocompatibility-2 Complex. Springer-Verlag, New York. 563 pp.

3. Katz, D. H. and B. Benacerraf, editor. 1976. The Role of Products of the Histocompatibility Gene Complex in Immune Responses. Academic Press, Inc., New York, 1976.

4. Thorsby, E., and A. Piazza. 1975. Joint Report from the VIth International Histocompatibility Testing Workshop II. Typing for HLA-D (LD-I or MLC) determinants. In Histocompatibility Testing 1975. F. Kissmeyer-Nielsen, editor. Munksgaard, Copenhagen. 414-458.

5. McMichael, A. J., and T. Sasazuki. 1977. A suppressor T cell in the human mixed lymphocyte reaction.J. Exp. Med. 146: $368-380$.

6. Yam, L. T., C. Y. Li, and W. H. Crosby. 1971. Cytochemical identification of monocytes and granulocytes. Am.J. Clin. Pathol. 55: 283-290.

7. Bobrove, A. M., S. Strober, L. A. Herzenberg, and J. D. DePamphilis. 1975. Identification and quantitation of thymus-derived lymphocytes in human peripheral blood. J. Immunol. 112: 52()-527.

8. Wilson, A. B., A. J. Haegert, and R. A. Coombs. 1975. Increased sensitivity of the rosette forming reaction of human $\mathrm{T}$ lymphocytes with sheep erythrocytes afforded by papain treatment of the sheep cells. Clin. Exp. Immunol. 22: 171-182.

9. Kovithavongs, T., M. C. McConnachie, and J. B. Dosseter. 1974. Immunity to tissue sensitization, HLA and nonHLA as detected by the ABCIL system. Transplantation. 17: 453-461.

10. Sasazuki, T., A. McMichael, R. Payne, F. C. Grumet, R. Radvany, B. Colombe, H. McDevitt, P. Stastny, L. Marchuk, and J. Dosseter. 1974. New and previously recognized MLC alleles. In Histocompatibility Testing 1975. F. Kissmeyer-Nielsen, editor. Munksgaard, Copenhagen. 464-469.

11. McMichael, A. J., T. Sasazuki, and H. O. McDevitt. 1977. The immune response to diphtheria toxoid in humans. Transplant Proc. 9: 191-194.

12. Reich, S. S., and R. R. Rich. 1975. Regulatory mechanisms in cell mediated immune responses II. A genetically restricted suppressor of the mixed lymphocyte reaction released by alloantigen activated spleen cells.J. Exp. Med. 142: $1391-1402$.

13. Rich, S. S., and R. R. Rich. 1976. Regulatory mechanisms in cell mediated immune responses. III. I-region control of suppressor cell interaction with responder cells in mixed lymphocyte reactions. J. Exp. Med. 143: 672-677.

14. Yunis, E. J., and D. B. Amos. 1971. Three closely linked genetic systems relevant to transplantation. Proc. Natl. Acad. Sci. U. S. A. 68: 3031-3035.

15. Meo, T., C. S. David, M. Nabholz, V. Miggrano, and D. C. Shreffler. 1973. A major role for the Ir-1 region of the mouse $H-2$ complex in the mixed lymphocyte reaction. Transplant Proc. 5: 377-381.

16. Widmer, M. B., C. Omodei-Zorini, F. H. Back, and J. Klein. 1973. Importance of different regions of $H-2$ for MLC stimulation. Tissue Antigens. 3: 309-315.

17. Shreffler, D. C., and C. S. David. 1975. The $H-2$ major histocompatibility complex and the $I$ immune region: genetic variation, function, and organization. Adv. Immunol. 20: 125-195.

18. Levine, B. B., R. H. Stember, and M. Fotino. 1972. Ragweed hayfever: Genetic control and linkage to HLA haplotypes. Science (Wash. D. C.). 178: 1201-1203.

19. Blumenthal, M. N., D. B. Amos, H. Noreen, N. Y. Mendell, and E. J. Yunis. 1974. Genetic mapping of Ir locus in man: linkage to second locus of HLA. Science (Wash. D. C.). 184: 1301-1303.

20. McMichael, A. J., and H. O. McDevitt. 1977. The association between the HLA system and disease. Prog. Med. Genet. 2: 39-100.

21. Swasdikul, D., and M. Block. 1972. Effect of radiation upon the "embryonic" thymus. Radiat. Res. 50: 73-84.

22. Miller, J. F., P. M. DeBurgh, P. Dukor, G. Grant, V. Allman, and W. House. 1966. Regeneration of thymus grafts. II. Effects on immunological capacity. Clin. Exp. Immun. 1: 61-76.

23. Duffy, B. J. and P. J. Fitzgerald. 1950. Thyroid cancer in childhood and adolescence: a report of twenty-eight cases. Cancer. 3: 1018-1032.

24. Goh, K., M. M. Reddy, and L. H. Hempelmann. 1970. Chromosome aberration in lymphocytes of normal adults long after thymic irradiation. Radiat. Res. 67: 82-85.

25. Reddy, M. M., D. Goh, and L. H. Hempelmann. 1976. B and $T$ lymphocytes in man: I. Effect of infant thymus irradiation on the circulatory $\mathrm{B}$ and $\mathrm{T}$ lymphocytes. In Radiation and the Lymphocyte System Proceedings of the 14th Annual Hanford Biological Symposium (CONF74093, ERDA Symposium Series 37) National Information Service, U. S. Department of Commerce Springfield, Va. $192-196$.

26. Reiger, C. H. L., S. C. Kraft, and R. M. Rothberg. 1975 Alterations of $\mathrm{T}$ cell function in healthy persons with a history of thymic x-irradiation. J. Allergy and Clin. Immunol. 56: 273-281.

27. Waldmann, T. A., M. Durm, S. Broder, M. Blackman, R. M. Blaese, and W. Strober. 1974. Role of suppressor T cells in pathogenesis of common variable hypogammaglobulinemia. Lancet. II: 609-613.

28. Stobo, J. D., S. Paul, R. E. Van Scoy, and P. E. Hermans 1976. Suppressor thymus-derived lymphocytes in fungal infection. J. Clin. Invest. 57: 319-328.

29. Twomey, J. J., A. H. Laughter, S. Farrow, and C. C. Doublass. 1975. Hodgkin's disease. An immunodepleting and immunosuppressive disorder. J. Clin. Invest. 56: $467-475$. 